\title{
Internal Control: A Tool for Fraud Control in Deposit Money Banks in Nigeria
}

\author{
Ugwu, James Ike Ph.D \\ Department of Accounting and Finance, Godfrey Okoye University, Enugu, Nigeria \\ Ochuba, Uche Lucia \\ Bursary Department, Federal College of Education, Ehamufu, Nigeria \\ PG Student, Department of Accounting and Finance, Godfery Okoye University, Enugu, Nigeria
}

\begin{abstract}
The quest to curtail or eliminate frauds, errors and irregularities has made the institution of appropriate internal control inevitable in organization especially banks where the object of trade is money. The study therefore explored the use of internal control as a tool for fraud control in deposit money banks in Nigeria. Survey research design was adopted for the study with data collected using structured questionnaire from fifteen deposit money banks in Enugu metropolis. Result of hypothesis tested using Chi-Square (Fisher's Exact Test) indicates that control environment, control activities and monitoring activities contribute significantly towards fraud control in an organization. The implication of the finding is that internal control is a vital the tool that protect organizations without which the organization must collapse due to fraud. One of the recommendations is that management should always ensure that strong and appropriate control activities are always in place to prevent financial leakages and promote accountability in the organization.. To that effect, there should also be appropriate segregation of duties to reduce a person's opportunity to commit and conceal fraud or errors. Also, appropriate level of management should approve and authorize all transactions within a specified limit, and authorization should require dual signature. Also, there should be secured facilities and controlled access to computer programs and data files.
\end{abstract}

Keywords: Internal Control, Control Environment, Control Activities, Monitoring Activities, Fraud, Deposit Money Banks, Nigeria

DOI: $10.7176 / \mathrm{EJBM} / 13-13-07$

Publication date:July $31^{\text {st }} 2021$

\subsection{Introduction}

Internal control which protect, guide and direct an organization in combination with good corporate governance, is the strength of every organization, as such, is of great importance in Nigerian banking sector. Banks, the financial hub of every nation, playing pivotal role in a nation's economy, has been characterized by poor corporate governance, macro-economic instability, slow growth, corruption and fraud, risk and uncertainty of going concern in Nigeria.

Commission of Sponsoring Organization (COSO) (2010) views the internal control as a process, put in place by organization's board of directors, management and other personnel aimed at providing some degree of guarantee towards goal accomplishments in effective and efficiency operation such that the reports are dependable while obeying relevant rules and regulations, This definition places responsibilities on the management of organizations to ensure the safety of resources and its full utilization for optimal productivity and that financial statements are accurate; reflecting true state of affairs of the organization at all time. Notwithstanding that no matter the level of internal controls system instituted by an organization, it cannot obliterate all errors, frauds and irregularities. It however, should be able to get management aware of possible problems, which can be nibbed in the bud (Campbell \& Harther, 2010).

The highest management level (board of directors) in the organization and its audit committee have the responsibilities of making sure that internal control within the organization is sufficient to ensure efficient and smooth operations in the organization. The responsibilities include determining the extent of internal controls and regular evaluation of the system, as well as, the internal and external auditors' involvement and advice the management. Internal control regular evaluation provides management with some confidence regarding its effectiveness (Tunji, 2013) Recent crisis in the financial system, as well as other corporate financial scandals in recent time, has demonstrated that in some organizations particularly financial institutions, internal control practices were ineffective or imperfect. Reports of the interview carried on the management revealed that majority of leaders of businesses in various organizations did not understand the risks they were exposed to (Ali, 2013). Management therefore, cannot set up effective internal control on matters they do not understand.

International Federation of Accountants (IFAC) noted that previously, many organizations focused on financial reporting controls until many more financial crises arose. These crises showed that many of the risks arose from other areas and externalities. Therefore, risk management and related internal control need 
multifaceted approach as organizations are affected by internal and external variables. Some variables from the external environment are beyond the control of the organization. Therefore, effectual internal control should be important parts of the responsibility of management at all levels to reduce risks (IFAC, 2012).

Tunji (2013) in his research on effectiveness of internal control system as antidote for distress in banking industry in Nigeria noted that poor internal controls system in any organization will lead to the failure or suffering of the organization. Karagiorgos, Droalas and Dimou (2013) in a similar study discovered a close association of most bank failure to fraud. In the United States (US) alone, bank failures rose to 200 percent in 1980s partly due to fraud and mismanagement. In the year 2014, 14 banks failed in the US which is a reduction as compared to the same period in 2013 where 16 banks failed (Tumin, 2014). In Nigeria, bank distress have been associated with fraudulent practices as in the case of former Oceanic bank. In 2009, Central Bank of Nigeria (CBN) while using forensic accountants on 5 deposit money banks uncovered fraud which lead to the prosecution of the chief executive of Oceanic bank by Economic and Financial Crimes Commission (EFCC) and was sentenced to 18 months in prison following her conviction by the court.

The rate and volume of fraud in Nigerian banking sector is high and has far reaching consequences as failure of a bank with wide spread of branches affects many people and economy hence the need to evaluate the contribution of internal control to fraud control in banks.

\subsection{Statement of the Problem}

The internal controls instituted by organizations are expected to prevent fraud and promote efficiency in the system. Equally expected from good internal control system is early detection of frauds, errors and irregularities. This is true as it provides security of assets, promote adherence to operational guideline/policy and procedure thus acting as whistle blowing mechanism amongst other functions.

Globally, financial fraud is as old as mankind and in Nigeria, it get prominence 1930s during industrial and commercial bank distress. Fraud grew in Nigeria to the extent that Osisioma (2012) describes fraud as an industry that employs many people with apprentices. The volume of unethical financial actions and other unwholesome (corrupt) practices in Nigeria earned her the position of $149^{\text {th }}$ out of 180 countries assessed by Transparency International Corruption Index of 2020 in which she scored 25/100 (Transparency International, 2020).

Nigerian banks recorded 37,817 cases and lost N15.15 billion in the year, 2018 despite the efforts of regulatory authorities. The Nigerian Deposit Insurance Corporation (NDIC) made this known in ThisDay Newspaper August 1, 2018. According to the report, the fraud and forgery incidences were carried out by both bank staff and non-bank individuals.

These cases of fraud affect investors' confidence, as well as mobilization of savings by banks which would have been channeled into productive investments thus bringing about growth in the economy. If adequate savings are achieved it would make the banks solvent and profitable and build up the confidence of investors.

It is in the light of the above that the study was carried out to ascertain the contribution of internal control to fraud control in banks in Nigeria.

\subsection{Research Objectives}

The primary aim of the study is to critically examine internal control as a tool for fraud control in deposit money banks in Nigeria.

Specifically, the study want to:

1. Ascertain the extent control activities contribute towards fraud control in deposit money banks in Nigeria.

2. Establish the extent control environment helps in fraud control in deposit money banks in Nigeria.

3. Examine the contributions of monitoring activities towards fraud control in deposit money banks in Nigeria.

\subsection{Research Questions}

Based on the prior stated objectives of this research, the following research questions have been developed to be answered in due course of study:

a. To what extent do control activities contribute towards fraud control in deposit money banks in Nigeria?

b. To what extent has control environment helped in fraud control in deposit money banks in Nigeria?

c. How do monitoring activities contribute towards fraud control in deposit money banks in Nigeria?

\subsection{Research Hypothesis}

The following hypotheses stated in their null form were tested in the work

$\mathrm{H}_{\mathrm{o} 1}$ : No significant contribution from control activities towards fraud control in deposit money banks in Nigeria.

$\mathrm{H}_{\mathrm{o} 2}$ : Control environment has no significant contribution towards fraud control in deposit money banks in 
Nigeria.

$\mathrm{H}_{03}$ : Monitoring activities have no significant contribution towards fraud control in deposit money banks in Nigeria.

\subsection{Scope of the Study}

The study was carried out on fifteen (15) different deposit money banks in Enugu state, Nigeria-Access Bank, Diamond Bank, ECO Bank, FCMB, Fidelity, First Bank, GT Bank, Heritage Bank, Polaris Bank, Sterling Bank, Stanbic Bank, UBA, Unity Bank, Union Bank and Zenith Bank.

Also, the variables for internal control consists of: control activities, control environment and monitoring activities.

\subsection{REVIEW OF PREVIOUS WORKS}

Literature was reviewed in this order: conceptual review, theoretical framework, empirical review and research gap.

\subsection{Conceptual Review}

The study reviewed the concept of internal control, concept of fraud, control activities, control environment and monitoring activities.

\subsubsection{Internal Control}

The Institute of Chartered Accountants of England and Wales (ICAE \& W) (1986) defines internal control as the all control, financial or otherwise, put in place by management of enterprise to ensure orderliness and efficiency in operation, while complying with management policy, securing the assets as well as complete and accurate records. It is therefore a management function covering financial and non financial aspects of the organization to ensures orderliness, compliance with laid down laws and order and security of all the assets and operations.

Similar definition was given by Mayo (2006), as the measure taken by management of an organization to protect its resources against misuse, fraud, ineptitude; while making sure that correct record of accounts are kept and acting in line with the policy of the organization and performance assessment of divisions of the organization.

Furthermore, Millechamp (2000), defines internal control system as autonomous review of systems of control and performance quality. It therefore emphasizes monitoring of laid down control measures in the organization and assessing the adequacy or otherwise of the system.

From these definitions, internal control comprises the plan, procedures, methods and measures put in place in an organization to secure its resources, check the correctness of accounting of accounting data, thus promoting efficiency within the policy framework set by management. Thus, internal control can be viewed as all activities, processes and procedures put in place by management of an organization to engender smooth and efficient operation.

Horngren (1990) gave two types of internal control namely: administrative controls ( comprising plans, methods and procedures that enhance management planning and control of operation) and financial controls (authorization of transactions, safeguard of assets and accuracy of accounting records which decreases wastes, intentional errors and fraud).

Internal control has five components namely: control environment, control activities, monitoring processes, risk assessment (identifying, analyzing and responding to business risks which can be internal like errors and fraud or external like inflation exchange rate, interest rate etc) and information and communication system (processes and procedure for recording and reporting business transactions like purchases, sales, cash receipt and payment as well as ledger and journal entries)

\subsubsection{Objectives of Internal Control System}

According to the Committee of Sponsoring Organization (COSO) of the Treadway Commission (1999), these objectives are to:

1. Guarantee the effectiveness and efficiency of operations (protection of asset inclusive)

2. Guarantee the dependability on financial reports presented

3. Ensure adherence to relevant laws and regulations and

4. Ensure the implementation of instructions and directives issued by board and management

The Committee categorizes the above stated objectives of internal control system as a means to provide reasonable conviction that;

a. Resources are safe and used for the purposes they were acquired.

b. Business information are correct; and

c. Laws and regulations are complied to by the employees.

From the fore going, internal control is broad activity encompassing other aspects of the business like physical security, monitoring and so on. However, it does not encompass initiatives taken by the executives or 
management, like defining company strategies, setting objectives, taking management decisions, and handling risk or monitoring performance of different sections/units.

\subsubsection{Concept of fraud}

According to ICAN (2006), fraud consists of both the intentional misrepresentation in financial statements and use of trickery to get an undue benefit by the one or more persons, among management, employees, or third parties. This implies that fraud is criminal and carefully panned deceit of the users of the information for the eventual gain of the producer.

Megis (2003) also refer to fraud as the misrepresentation by person (s) of a material fact known by the person(s) to be false or made with regard as to whether the fact is true with intent to deceive the other party such that the individual is injured or hurt.. It is also a type of irregularities involving the use of criminal deceit to attain an undeserved or illegitimate gain.

In his own contribution, Archibong (1992), describes fraud as a premeditated and well planned tricky process or device undertaken by an individual or group of individuals, with the intention of attracting to individuals or group of individuals, ill-gotten benefits: monetary or otherwise, which would not have accrued in the absence of such deceitful act.

Fraud may involve; manipulation, falsification or alternation of documents and records; recording transactions without substances; misappropriate of assets or theft; intentional misapplication of accounting policies; suppressing of transactions or omitting such transaction from records and willful misrepresentation of transactions or the entity's state of affairs (Agyemang, 2020).

Fraud comes in different forms and magnitude. According to Biggs (2006), fraud could be classified into defalcation and manipulation while Megis (2003), also classified fraud into management fraud and employee fraud.

\subsubsection{Concept of Control Environment}

The control environment is a set of standards, processes, and structures upon which internal control across organization is based The top management of an organization establishes the guideline bearing in mind the importance of internal control. Control environment comprises the integrity and ethical values of the organization; the parameters enabling the top management to carry out its governance oversight responsibilities; the organizational structure and assignment of authority and responsibility; the process for attracting, developing, and retaining competent individuals; and the rigor around performance measures, incentives, rewards to drive accountability for performance, the way management assigns authority and responsibility, and organizes and develops its people (Ward \& Smith, 2002)

The resulting control environment has a pervasive impact on the overall system of internal control. It is the foundation for all other components of internal control as it provides discipline and structure. COSO (2013) Price Water House Coopers (PWC) (2012) indicated that, the control environment includes the governance and management functions and the attitudes, awareness, and actions of those charged with governance and management concerning the entity's internal control and its importance in the entity. Control environment, sets the tone of an institution and influences the control consciousness of its people. Control is also established at departmental or local control environment.

Elements of the control environment include.

a. The organizational structure of the institution; (The banks organogram defining the channel of communication and defined authorities and responsibilities).

b. Management's philosophy and operating style. (formal or informal business strategy as well as aggressive or conservative operating philosophy

c. The integrity, ethics, and competence of personnel.

d. The external influences that affect the bank's operations and risk management practices (e.g., independent audits).

e. The attention and route provided by the board of directors and its committees, especially the audit or risk management committees.

f. The effectiveness of human resources policies and procedures.

Jayne and Laura (2017) added that control environment set the tone of an organization, teach employees that right thing matters, setting expectations and appropriate behavior, addressing misconducts and other wrongdoings with commitment to competence by hiring the right staff and investment in employee education.

\subsubsection{Control activities}

The concept of control activities involves such activities as segregation of duties, authorization procedures and related responsibilities, adequate documentation and records, and protection of assets and records. In the light of the above, there are internal checks and balances as such there are approval limits and designated officer for such. Furthermore, no officer can start a transaction and handle it till the end. Proper recording is emphasized while adequate protection of assets and records from unauthorized access and use as well as against theft are put in place. It also encompasses approvals, verification and reconciliation occurring throughout the organization at all 
levels and in all functions (Layne \& Laura, 2017)

\subsubsection{Monitoring Activities}

These are used by management to ensure that controls are operating properly and that controls are modified in line with changes in assessment of risks which may reveal weaknesses in internal control. Usually, internal audit is used to ensure control or monitor control. This implies that even when there have been some measures of control put in places there must be in place a monitoring system to ensure compliance and early detection of breaches whenever they occur. The above could be achieved through continuous monitoring activities, intermittent evaluation or both.

\subsection{Theoretical Review: Differential opportunity Theory by Comer (1985)}

Comer put forward the theory based on the fact that every employee has the opportunity to commit fraud against the employer, against the supplier, against the customers of their employer, as well as, against third parties including government departments. Thus, the accessibility of the perpetrator to the accounts, assets, computer and premises of the organization, the skill possessed by the perpetrator to identify that such opportunity exist and to be used and the availability of adequate time to plan and execute the fraud are vital for fraud to occur. However, the opportunities is checked or regulated by the standard of internal control in place in the organization. The theory is appropriate for the study in that the internal controls put in place by organization aims at safe guard of assets, early detection of deviation from the organizational policies and procedures, effective and efficient running of the organization amongst others. In essence, internal control limits the occurrence of fraud.

\subsection{Empirical Review}

The interaction between internal control and fraud in banks has been attracting attention of scholars with a lot of empirical works yet without consensus. Some of those works were reviewed below.

Haladu (2018) examined internal control measures for fraud prevention and detection in deposit money banks (DMBs) listed in Nigerian Stock Exchange (NSE). Proxies for internal control were control environment, risk assessment and control activities while discretional accruals were the proxies for fraud prevention and detections. The result of analysis revealed negative influence of internal control proxies on discretional accruals, however, risk assessment had insignificant.

Furthermore, Oguda, Odhiambo and Byaruhanga (2015), verified the influence of internal control on fraud prevention and detection in Kakamenga County, Kenya, using purposive sampling method. Data were analysed using descriptive and inferential statistics. It was revealed that positive and significant relationship exists between internal control and fraud prevention and detection in district treasuries of Kakamenga County.

In the same vein, Okonkwo and Ezegbu (2016), evaluated how internal control system in banks have facilitated in mitigating or preventing frauds in Nigerian banks. Using survey research design, findings include that internal control were not effective in checking frauds with branch managers as the major actors in fraudulent activities in Nigerian banks.

In a similar study, Agyemang,(2020), assessed the effect of internal control on fraud prevention. Analysis of data collected through questionnaire using percentage suggests that good internal control and effective supervision and monitoring of internal control are capable of preventing and detecting fraud and fraudulent practices in Nigerian banks. Furthermore, Abiola and Oyewole (2013) explored the effect of internal control system on fraud detection in commercial banks in Nigeria. Results of data analysis using General Least Square, Correlation and Panel data analyses showed statistically significant relationship between employee training and fraud control amongst others

Njoki (2016) in a explored internal audit functions and fraud detection among insurance companies operating in Kenya. He adopted a descriptive research designs and carried out census study of 41 insurance companies in Kenya. T-test result of analysis of primary data were collected using a structured established that there was a statistical relationship between Proactive Fraud Audit, Compliance to Policies, Risk Management, Control of Operation and Financial Reporting and fraud detection among insurance companies in Kenya.

In a similar study, Adeniji (2004), in a case study of Power Holding Company of Nigeria examined the impact of internal audit on fraud detection and prevention. Data were collected using questionnaires and from company's financial statement. Chi-square result was suggestive that internal audit exhibits important function in public sector.

Furthermore, Onyinlola (2010), examined the role of auditors in the detection, prevention and reporting of fraud in the manufacturing sector in Nigeria. Data obtained from 184 respondents on analysis revealed that the respondents placed very high expectation on auditors' duties on fraud prevention and detection which is in contrast to primary duties of an auditor.

In their contribution, Samuel, Mohamed and Simon (2016), investigated the use of control activities in fraud control in financial institutions using a case of financial institutions in Meru town, Kenya. The study 
targeted a total of 106 respondents who included 20 managers and 86 supervisors of various financial institutions operating in Meru town, Kenya. The study used the questionnaire as a tool of collecting primary data and the hypotheses formulated were tested using chi-square statistical tool. The result of the findings established a significant relationship between control activities and fraud control.

Chimeocha (2018) examined internal audit as an effective tool for fraud control in manufacturing organization using Michelle Laboratory as a case study. The study adopted a survey research design and primary data was collected using questionnaire. T-test result shows that internal audit has statistical significance association with fraud prevention in manufacturing organization.

\subsection{Summary of Literature Review/Gap}

Various literatures that were reviewed above and it was obvious that there was no uniformity in the approaches as well as variables adopted in their studies so far. Adeniji (2004), Njoki (2016) and Onyinlola (2010) examined the role of internal audit in fraud prevention and detection while Samuel, Mohammed and Simon (2016), investigated the use of internal control in fraud control but used only control activities in their study of banks in Meru Kenya. Similarly, Okonkwo and Ezegbu (2016), Oyewole (2013), and Haladu (2018) investigated internal control and fraud prevention and control but differed from the current study on the account of variables used to proxy for internal control. The study wants to ascertain the contribution of control activities, control environment and monitoring processes on fraud control in Nigerian banks. This is an expansion of the study and in a different environment; Enugu, Nigeria.

\subsection{METHODOLOGY}

The study adopted survey research design. The population of the study consists of 357 staff of banks that were within Enugu which comprise of 89 management staff (15 branch managers and 74 departmental managers) and 268 clerks. The study used questionnaire as a tool of collecting primary data. The questionnaire were designed in a way that the respondents were required to tick the appropriate answer according to their assessment based on modified four point Likert scale. The researcher prepared a list of questions based on the research objectives in order to solicit information from the target population; the questions were closed ended.

The study adopted Taro Yamane formula in determining sample size of 286 from a population of 357 . The sample was proportionately distributed among the 15 banks of study in line with their staff strength in the population of study.

On reliability, the research adopted Cronbach approach which recommended that alpha value for each variable under study should not be less than 0.6 (Mohsen \& Reg, 2011). The alpha value of 0.805 was derived by the use of Statistical Package for Social Sciences(SPSS). Face and content validity were adopted in validating the study.

In analyzing the data, non-parametric statistical tools of Pearson Chi-Square was used. All the hypotheses were tested using the Fisher's Exact Test statistic at 5\% level of significance.

\subsection{DATA PRESENTATION AND ANALYSIS}

This section deals with the presentation and analysis of the responses from the staff of 15 deposit money banks that were within Enugu Metropolis. The researchers administered 286 copies of the questionnaire of which 214 copies were returned, therefore 214 copies were found useful. 
Table 1: Analysis of Field Data

\begin{tabular}{|c|c|c|c|c|c|c|c|c|c|}
\hline $\mathrm{S} / \mathrm{N}$ & Questions & $\begin{array}{l}\text { SA } \\
(4)\end{array}$ & $\begin{array}{l}\text { A } \\
(3)\end{array}$ & $\begin{array}{l}\text { D } \\
(2)\end{array}$ & $\begin{array}{l}\text { SD } \\
(1)\end{array}$ & $\mathbf{N}$ & $\begin{array}{l}\text { Weight } \\
\text { in Total }\end{array}$ & $\begin{array}{l}\text { Mean } \\
(\mathbf{W T} / \mathbf{N})\end{array}$ & $\begin{array}{l}\text { Cluster } \\
\text { Grand } \\
\text { Mean }\end{array}$ \\
\hline \multicolumn{10}{|c|}{ A. Control Activities } \\
\hline 1. & $\begin{array}{l}\text { Review of operating performance and } \\
\text { exception reports is necessary for } \\
\text { controlling of fraud. }\end{array}$ & 107 & 59 & 27 & 21 & 214 & 680 & 3.18 & 3.05 \\
\hline 2. & $\begin{array}{l}\text { An appropriate level of management } \\
\text { should approve and authorize all } \\
\text { transactions over a specified limit, and } \\
\text { authorization should require dual } \\
\text { signature. }\end{array}$ & 98 & 71 & 24 & 21 & 214 & 674 & 3.15 & 3.05 \\
\hline 3. & $\begin{array}{l}\text { There should be appropriate } \\
\text { segregation of duties to reduce a } \\
\text { person's opportunity to commit fraud } \\
\text { and conceal fraud or errors. }\end{array}$ & 90 & 60 & 41 & 23 & 214 & 645 & 3.01 & 3.05 \\
\hline 4. & $\begin{array}{l}\text { There should be secure facilities and } \\
\text { control access to computer programs } \\
\text { and data files. }\end{array}$ & 55 & 79 & 46 & 34 & 214 & 583 & 2.72 & 3.05 \\
\hline 5. & $\begin{array}{l}\text { Independent checks on whether jobs } \\
\text { are getting done and recorded amounts } \\
\text { are accurate helps to prevent fraud. }\end{array}$ & 108 & 60 & 25 & 21 & 214 & 683 & 3.19 & 3.05 \\
\hline B. & \multicolumn{9}{|l|}{ Control Environment } \\
\hline 1. & $\begin{array}{l}\text { Well-designed reporting relationships } \\
\text { help to prevent fraud. }\end{array}$ & 90 & 66 & 37 & 21 & 214 & 653 & 3.05 & 2.91 \\
\hline 2. & $\begin{array}{l}\text { Conservative management philosophy } \\
\text { and operating style help to control } \\
\text { fraud }\end{array}$ & 72 & 79 & 36 & 27 & 214 & 624 & 2.92 & 2.91 \\
\hline 3. & $\begin{array}{l}\text { External influences affect the bank's } \\
\text { operation and risk management }\end{array}$ & 66 & 90 & 37 & 21 & 214 & 629 & 2.94 & 2.91 \\
\hline 4. & $\begin{array}{l}\text { The attention and direction provided } \\
\text { by the board of directors and its } \\
\text { committees, especially the audit or risk } \\
\text { management committees helps to } \\
\text { reduce fraud. }\end{array}$ & 88 & 64 & 36 & 26 & 214 & 642 & 3 & 2.91 \\
\hline 5. & $\begin{array}{l}\text { The effectiveness of human resources } \\
\text { policies and procedures reduce fraud. }\end{array}$ & 50 & 79 & 45 & 40 & 214 & 567 & 2.65 & 2.91 \\
\hline C. & \multicolumn{9}{|l|}{ Monitoring Activities } \\
\hline 1. & $\begin{array}{l}\text { Internal and external audit functions } \\
\text { are used as part of the organisation's } \\
\text { monitoring program. }\end{array}$ & 103 & 69 & 21 & 21 & 214 & 682 & 3.19 & 3.52 \\
\hline 2. & $\begin{array}{l}\text { There is effective risk identification } \\
\text { and analysis to help monitor fraud. }\end{array}$ & 82 & 87 & 24 & 21 & 214 & 658 & 3.08 & 3.52 \\
\hline 3. & $\begin{array}{l}\text { Established monitoring and follow-up } \\
\text { processes help to prevent fraud } \\
\text { activities. }\end{array}$ & 97 & 72 & 23 & 22 & 214 & 672 & 3.14 & 3.52 \\
\hline 4. & $\begin{array}{l}\text { Accurate and timely information flows } \\
\text { prevent fraud activities. }\end{array}$ & 82 & 87 & 24 & 21 & 214 & 658 & 3.08 & 3.52 \\
\hline
\end{tabular}

Source: Author's computation 2019.

\subsection{Testing the Research Hypotheses}

In this section, the hypotheses earlier stated in this study in their null form were tested using Fisher's exact test. The critical or table value are compared with the computed P-value to decide whether to reject or accept a hypothesis.

\subsubsection{Testing Hypothesis 1}

$\mathrm{H}_{\mathrm{o} 1}$ : Control activities have no significant contribution towards fraud control in deposit money banks in Nigeria. 
Table 2:CONTROL ACTIVITIES CHI-SQUARE TABLE

Case Processing Summary

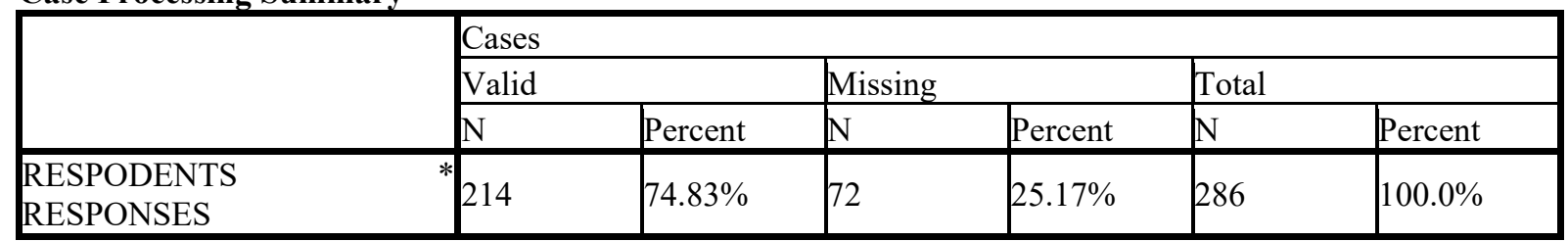

Source: Author's computation 2019 using SPSS Output file (Version 21.0)

Table 3: RESPODENTS * RESPONSES Crosstabulation

Count

\begin{tabular}{|c|c|c|c|c|c|c|c|}
\hline & \multicolumn{5}{|c|}{ RESPONSES } & \multirow[b]{2}{*}{ Total } \\
\hline & & SA & A & D & SD & 5 & \\
\hline \multirow[t]{3}{*}{ RESPODENTS } & CLERKS & 28 & 34 & 36 & 19 & 1 & 118 \\
\hline & $\begin{array}{l}\text { DEPARMENTAL } \\
\text { MANAGERS }\end{array}$ & 11 & 13 & 13 & 16 & 0 & 53 \\
\hline & BRANCH MANAGERS & 9 & 10 & 13 & 11 & 0 & 43 \\
\hline Total & & 48 & 57 & 62 & 46 & 1 & 214 \\
\hline
\end{tabular}

Source: Author's computation 2019 using SPSS Output file (Version 21.0)

Table 4: Chi-Square Tests

\begin{tabular}{|c|c|c|c|c|c|c|}
\hline & Value & Df & $\begin{array}{l}\text { Asymptotic } \\
\text { Significance } \\
\text { (2-sided) }\end{array}$ & $\begin{array}{l}\text { Exact Sig. (2- } \\
\text { sided) }\end{array}$ & Exact Sig. (1- & $\begin{array}{l}\text { Point } \\
\text { Probability }\end{array}$ \\
\hline $\begin{array}{l}\text { Pearson Chi-Square } \\
\text { Likelihood Ratio } \\
\text { Fisher's Exact Test } \\
\text { Linear-by-Linear } \\
\text { Association } \\
\mathrm{N} \text { of Valid Cases }\end{array}$ & $\begin{array}{l}8.538^{\mathrm{a}} \\
8.347 \\
8.761 \\
4.633^{\mathrm{b}} \\
214 \\
\end{array}$ & $\begin{array}{l}8 \\
8 \\
1\end{array}$ & $\begin{array}{r}.383 \\
.400 \\
.031\end{array}$ & $\begin{array}{l}.403 \\
.404 \\
.370 \\
.033\end{array}$ & .018 & .005 \\
\hline
\end{tabular}

a. 8 cells $(53.3 \%)$ have expected count less than 5 . The minimum expected count is .12 .

b. The standardized statistic is -2.152 .

Source: Author's computation 2019 using SPSS Output file (Version 21.0)

From table 4 above, the latter has 8 cells $(53.3 \%)$ with expected count less than 5; giving minimum expected count of 0.12 . With a significance level of 0.05 , the hypothesis is tested using Fisher's exact test.

Decision Rule: Since the test statistics, that is the P-values: 0.370 is greater than 0.05 , we accept the alternative hypotheses stated implicitly. Therefore, it is concluded that Control activities have significant contribution towards fraud control in deposit money banks in Nigeria.

\subsubsection{Testing Hypothesis 2}

$\mathrm{H}_{02}$ : Control environment has no significant contribution towards fraud control in deposit money banks in Nigeria.

Table 5: CHI-SQUARE TABLE FOR CONTROL ENVIRONMENT.

Case Processing Summary

\begin{tabular}{|c|c|c|c|c|c|c|}
\hline & \multicolumn{6}{|c|}{ Cases } \\
\hline & \multicolumn{2}{|c|}{ Valid } & \multicolumn{2}{|c|}{ Missing } & \multicolumn{2}{|c|}{ Total } \\
\hline & $\mathrm{N}$ & Percent & $\mathrm{N}$ & Percent & $\mathrm{N}$ & Percent \\
\hline $\begin{array}{l}\text { RESPODENTS } \\
\text { RESPONSES }\end{array}$ & 214 & $74.83 \%$ & 72 & $25.17 \%$ & 286 & $100.0 \%$ \\
\hline
\end{tabular}

Source: Author's computation 2019 using SPSS Output file (Version 21.0) 
Table 6: RESPODENTS * RESPONSES Cross tabulation

Count

\begin{tabular}{|ll|l|l|l|l|l|l|l|}
\hline & & \multicolumn{3}{|l|}{ RESPONSES } & \\
\cline { 4 - 6 } & & SA & A & D & SD & 5 & Total \\
\hline RESPODENTS: & CLERKS & 28 & 34 & 36 & 19 & 1 & 118 \\
& DEPARMENTAL MANAGERS & & 11 & 13 & 13 & 16 & 0 & 53 \\
& BRANCH & & & & & & \\
& MANAGERS & 9 & 10 & 13 & 11 & 0 & 43 \\
& & & 48 & 57 & 62 & 46 & 1 & 214 \\
\hline
\end{tabular}

Source: Author's computation 2019 using SPSS Output file (Version 21.0)

Table 7: Chi-Square Tests

\begin{tabular}{|l|l|l|l|l|l|l|}
\hline & Value & Df & $\begin{array}{l}\text { Asymptotic } \\
\text { Significance } \\
\text { (2-sided) }\end{array}$ & $\begin{array}{l}\text { Exact Sig. (2- } \\
\text { sided) }\end{array}$ & $\begin{array}{l}\text { Exact Sig. (1- } \\
\text { sided) }\end{array}$ & $\begin{array}{l}\text { Point } \\
\text { Probability }\end{array}$ \\
\hline Pearson Chi-Square & $7.421^{\mathrm{a}}$ & 6 & .284 & .288 & & \\
Likelihood Ratio & 8.556 & 6 & .200 & .235 & \\
Fisher's Exact Test & 7.754 & & .246 & .165 & .028 \\
Linear-by-Linear & $1.078^{\mathrm{b}}$ & 1 & .299 & .314 & & \\
Association & 214 & & & & & \\
N of Valid Cases & & & & & \\
\hline
\end{tabular}

a. 5 cells $(41.7 \%)$ have expected count less than 5 . The minimum expected count is 2.88 .

b. The standardized statistic is -1.038 .

Source: Author's computation 2019 using SPSS Output file (Version 21.0)

From table 7 above, 5 cells $(41.7 \%)$ have expected count less than 5, giving minimum expected count of 2.88 . With a significance level of 0.05 , the hypothesis is tested using Fisher's exact test.

Decision Rule: Since the test statistics, that is the P-values: 0.246 is greater than 0.05 , we accept the alternative hypotheses stated implicitly. Therefore, it is concluded that control environment has significant contribution towards fraud control in deposit money banks in Nigeria.

\subsubsection{Testing Hypothesis 3}

$\mathrm{H}_{03}$ : Monitoring activities has no significant contribution towards fraud control in deposit money banks in Nigeria.

\section{CHI-SQUARE TABLE FOR CONTROL ENVIRONMENT}

Table 8: Case Processing Summary

\begin{tabular}{|c|c|c|c|c|c|c|}
\hline \multicolumn{7}{|c|}{ Cases } \\
\hline & \multicolumn{2}{|c|}{ Valid } & \multicolumn{2}{|c|}{ Missing } & \multicolumn{2}{|c|}{ Total } \\
\hline & $\mathrm{N}$ & Percent & $\mathrm{N}$ & Percent & $\mathrm{N}$ & Percent \\
\hline RESPODENTS * RESPONSES & 214 & $74.83 \%$ & 72 & $25.17 \%$ & 286 & $100.0 \%$ \\
\hline
\end{tabular}

Source: Author's computation 2019 using SPSS Output file (Version 21.0)

Table 9: RESPODENTS * RESPONSES Cross-tabulation Count

\begin{tabular}{|c|c|c|c|c|c|c|c|}
\hline & \multicolumn{5}{|c|}{ RESPONSES } & \multirow[b]{2}{*}{ Total } \\
\hline & & SA & A & $\mathrm{D}$ & $\mathrm{SD}$ & 5 & \\
\hline \multirow[t]{4}{*}{ RESPODENTS } & CLERKS & 28 & 34 & 36 & 19 & 1 & 118 \\
\hline & $\begin{array}{l}\text { DEPARMENTAL } \\
\text { MANAGERS }\end{array}$ & 11 & 13 & 13 & 16 & 0 & 53 \\
\hline & BRANCH MANAGERS & 9 & 10 & 13 & 11 & 0 & 43 \\
\hline & & 48 & 57 & 62 & 46 & 1 & 214 \\
\hline
\end{tabular}

Source: Author's computation 2019 using SPSS Output file (Version 21.0) 
Table 10: Chi-Square Tests

\begin{tabular}{|c|c|c|c|c|c|c|}
\hline & Value & $\mathrm{df}$ & $\begin{array}{c}\text { Asymptotic } \\
\text { Significance } \\
\text { (2-sided) }\end{array}$ & $\begin{array}{l}\text { Exact Sig. (2- } \\
\text { sided) }\end{array}$ & $\begin{array}{l}\text { Exact Sig. (1- } \\
\text { sided) }\end{array}$ & $\begin{array}{c}\text { Point } \\
\text { Probability }\end{array}$ \\
\hline $\begin{array}{l}\text { Pearson Chi-Square } \\
\text { Likelihood Ratio } \\
\text { Fisher's Exact Test } \\
\text { Linear-by-Linear } \\
\text { Association } \\
\text { N of Valid Cases }\end{array}$ & $\begin{array}{c}7.421^{\mathrm{a}} \\
8.556 \\
7.754 \\
1.078^{\mathrm{b}} \\
214\end{array}$ & $\begin{array}{l}6 \\
6\end{array}$ & $\begin{array}{l}.284 \\
.200 \\
.299\end{array}$ & $\begin{array}{l}.288 \\
.235 \\
.246 \\
.314\end{array}$ & .165 & .028 \\
\hline
\end{tabular}

a. 5 cells $(41.7 \%)$ have expected count less than 5 . The minimum expected count is 2.88 .

b. The standardized statistic is -1.038 .

Source: Author's computation 2019 using SPSS Output file (Version 21.0)

From table 10, 11 cells $(61.1 \%)$ have expected count less than 5 . The minimum expected count is 0.2 ; therefore the Pearson Chi-Square will not be used as the value of the test statistic. With a significance level of 0.05 , the hypothesis is tested using Fisher's Exact Test.

Decision Rule: Since the test statistics, that is the P-values: 0.431 is greater than 0.05 , we accept the alternative hypotheses stated implicitly. Therefore, it is concluded that monitoring activities has significant contribution towards fraud control in deposit money banks in Nigeria.

\subsection{Discussion of Findings}

The primary aim of this study is to critically examine internal control as a tool for fraud control in deposit money banks in Nigeria. The following were revealed from analysis of date.

Test of hypothesis 1 showed that control activities have significant contribution towards fraud control in deposit money banks in Nigeria. This is in agreement with the apriori expectation as it generally expected that good control activities should be able to keep fraud in check to a great extent. This finding is in agreement with the finding of Samuel, Mohamed and Simon (2016) and Haladu (2018) who established that significant relationship exist between Control Activities and fraud control. Effective control activities will ultimately reduce or remove completely fraud in deposit money banks as it entails provision of physical security to assets, as well as access code to computer data base thus preventing theft/fraud. Also, approvals and authorization of financial transactions are put in control by designating an officer for such and also tagging approval limits depending on the officer and organizational policy. However, this finding does not conform with that of Aruonoaghe and Ikyume (2013) who were in their work found a negative but non significant association between control activities and level of fraud prevention and detection. The above may not be unconnected with the volume of fraud going on in banks which most of time were unreported to avoid loss of confidence by the banking public. The result from hypothesis 2 revealed 0.284 significance which is greater than the significance level of signifance of 0.05 . This simply implies that control environment has significant contribution towards fraud control in deposit money banks in Nigeria. This could be explained by the fact that control environment has all encompassing influence on the structure of business activities and how they are carried out, the way objectives are established, the way risks are assessed and fraud detected and addressed. Having such wide spread influence on various aspect of the organization, if properly handled/ controlled, would definitely have great contribution on fraud control. This finding agrees with Price Water House Coopers (PWC) (2012) which indicated that control environment is the foundation for all other components of internal control.

The result of the chi-square test in hypothesis 3 revealed 0.284 significance value which is above 0.05 value set for alpha. Therefore, the hypothesis which states that monitoring activities has no significant contribution towards fraud control in deposit money banks in Nigeria is rejected. This is in agreement with the apriori expectation as good monitoring/supervision of internal control would help to ensure strict application of the measures hence better result. Internal control are usually well articulated and it is only on close supervision to ensure compliance that could enforce compliance.

\subsection{Summary of findings, Conclusion and Recommendations}

5.1 Summary of Findings

The study revealed the following:

1. Control activities have significant contribution towards fraud control in deposit money banks in Nigeria.

2. Control environment has significant contribution towards fraud control in deposit money banks in Nigeria.

3. Monitoring activities has significant contribution towards fraud control in deposit money banks in Nigeria. 


\subsection{Conclusion}

From the research conducted, internal control can be used as an effective tool for fraud control in deposit money banks in Nigeria. Poor internal control would precipitate fraud, loss of funds and poor responsibility accounting. Growth and development of an organization lies on the quality of internal control put in place by the management.

\subsection{Recommendations}

Having conducted this research and analyzed the field data, the researcher recommends the following points, which if adhered to will positively bridge the gender gap.

1. Control activities have statistical association on level of fraud prevention and detection in deposit money banks in Nigeria, management should always ensure that strong and appropriate control activities are always in place to prevent financial leakages and promote accountability in the firm. There should also be appropriate segregation of duties to reduce a person's opportunity to commit fraud and conceal fraud or errors and an appropriate level of management should approve and authorize all transactions over a specified limit, and authorization should require dual signature. Also, there should be secure facilities and control access to computer programs and data files.

2. Control environment having significant statistical association with fraud control deposit money banks in Nigeria, then management should prepare a well-designed reporting system and conservative management philosophy and operating style should be adopted. External influences that affect the bank's operation and risk management should be avoided and also human resources policies and procedures should be made effective.

3. Finally, since result showed that monitoring activities has significant contribution towards fraud control in deposit money banks in Nigeria, management should ensure that internal and external audit functions are used fully as part of the organization's monitoring program and also, monitoring and follow up processes must be established to prevent fraudulent activities.

\subsection{Contributions to Knowledge}

This study has helped in showing how internal control components can be used to prevent fraud in banks in Nigeria.

The study has also contributed to the enrichment of the literature on relevance of internal control system as a tool for fraud control in banks. It has also thrown more light to students, scholars and academics on the relationship between control environment, control activities, monitoring activities and fraud in banks.

\subsection{Area for Further Research}

Other researchers can look into internal control as a tool for fraud control in manufacturing companies in Nigeria. Risk assessment a tool for fraud control in deposit money banks in Nigeria.

\section{References}

Abiola, I. \& Oyewole, A. T. (2013). Internal control system and fraud Detection: Nigeria Experience. Journal of Accounting and Finance, 13(5), 141-152

Adeniji, A. (2004): Auditing and Investigation. Lagos, Value Analysis Publishers

Agyemang, J. K. (2020). Internal control and fraud prevention. International Journal of Scientific Research and Management Studies 1-11

Ali, Z. S. (2013). Contribution of internal control system to the financial performance of financial institution a case of people's Bank Of Zanzibar Ltd.

Archibong .M. (1992) .The internal auditor as fraud- buster. Managerial Auditing Journal, 14 (7), 351-363.

Aruomoaghe, J. A. \&Ikyume, J. C. (2013). Accounting for fraud in Nigeria: The banking sector in focus, International Journal of Research in Management 3(6), 59-73.

Biggs W. W. (2006). Practical auditing, hybrid publisher limited.

Campbell, S. \& Hartcher, J. (2010). Internal Controls for Small Business. NATIONAL OFFICE CPA Centre Level 28, 385 Bourke Street Melbourne

Chimeocha. G. (2018): Internal audit as an effective tool for fraud control in manufacturing organization a study of Michelle laboratory. Available at http://eprints.gouni.edu.ng/id/eprint/506

Comer, M. J. (1985) Corporate Fraud. London: McGrawHill Company (UK) Limited

Haladu, A. (2018).fraud detection and internal control measures in deposit money banks listed in Nigerian stock exchange. International Journal of Science and Management Studies, 1(4), 43-54

ICAN (2006). Financial Reporting and Audit Practice, ICAN News 8 (4), 5-72.

International Federation of Accountants (2012). Evaluating and Improving Internal Controls. London:IFAC.

Jayne, B. \& Laura, S. (2017). Good internal control practices and fraud control tips. 
https://fa.uw.edu/audit/sites/default/files/Good-Internal-Control-Practices

Karagiorgos, T., Droalas, G. \&Dimou, A. (2013). Effectiveness of Internal Control System in Greek Banking Sector. International Journal of Academics Research in Business and Social Science. 425) 351-418

Mayo E. (2006). An analysis of problems encountered by auditors of small, medium and micro enterprises in Botswana, The SA Journal of Accounting Research.14 (1), 35-78.

Megis, W.T (2003). Principles of Auditing, 6th edition. Homewood, Illinois. Richard D, Irwin Inc.

Millichamp, W.C.(2000). Embracing risk-based auditing in internal corporate governance. Finance Review, June, 17-20.

Mohsen, T. \&Reg, D. (2011). Making sense of Crobach's Alpha. International Journal of Medical Education, 2(5). $53-55$

Njoki E. (2016). Effect of internal audit functions on fraud detection among insurance companies operating in Kenya. Journal of Finance and Management in Public Services, 14(1), 18-32.

Oguda, N. J., Odhiambo, A. \& Byaruhanga, J. (2015). Effect of internal control on fraud detection and prevention in treasuries of Kakamega County. International journal of Business and Management inovention, 4(1), 47-57.

Okonkwo, I. V. \& Ezegbu, N. L. (2016). Internal control techniques and fraud mitigation in Nigerian banks, Journal of Economics and Finance, 7(5), 37-46.

Onyinlola. A. O. (2010). The role of auditors in the detection, prevention and reporting of fraud in the manufacturing sector. International Journal of Academics Research in Business and Social Science.2(8), $306-414$

Osisioma, B. C. (2012). Combating fraud and white collar crimes: Lessons from Nigeria. A paper presented at $2^{\text {nd }}$ annual fraud and corruption African summit held at Zanzibar beach resort, Zanzibar Republic of Tanzania. May 22

Price water House Coopers (2012). The Internal Control system: A rapidly Changing Management Instrument. London. Author

Samuel D., Mohamed A. \& Simon H. (2016). Use of control activities in fraud control in financial institutions a study of financial institutions in meru town, Kenya. Journal of Finance and Management in Public Services, 14(1), 23-45.

The Committee of Sponsoring Organization (COSO) of the Treadway Commission (1999). Internal control-integrated framework, July 1999.

The Institute of Chartered Accountants of England and Wales (ICAE \& W) (1986)

Transparency International (2020). Corruption perceptions index

Tumin K., (2014). Third bank failures of 2014- Syringa Bank in Idaho. Depositaccounts.com

Tunji, S. (2013). Effective internal control system as an antidote for distress in banking industry in Nigeria. Journal of Economics and International Business Research. 1(5), $106-121$

Ward P. \& Smith Clifton L.. (2002). The development of access control policies for information technology systems. Computers \& Security, 21(4), 356-3 